
VOLUME 10 NOMOR 4 AGUSTUS 2021

ISSN : 2303-1514 | E-ISSN : 2598-5949

\title{
THE IMPACT OF PARENTING PATTERNS IN SIGNIFYING POLITENESS OF ELEMENTARY SCHOOL CHILDREN
}

Elma Elfiana Nurus Solehah ${ }^{1}$, Sekar Dwi Ardianti ${ }^{2}$, Imaniar Purbasari ${ }^{3}$

${ }^{1,2,3}$ Universitas Muria Kudus, Indonesia

IElmaelfiana123@gmail.com, ${ }^{2}$ sekardwiardianti@umk.ac.id, ${ }^{3}$ imaniarpurbasari@umk.ac.id

\section{DAMPAK POLA ASUH ORANG TUA DALAM PEMAKNAAN SIKAP SOPAN SANTUN ANAK USIA SEKOLAH DASAR}

\begin{tabular}{|c|c|}
\hline ARTICLE HISTORY & ABSTRACT \\
\hline $\begin{array}{l}\text { Submitted: } \\
\text { 04 Juli 2021 } \\
04^{\text {th }} \text { July } 2021\end{array}$ & $\begin{array}{l}\text { Abstract: The purpose of this study was to determine and describe the impact of parenting on } \\
\text { signifying polite attitudes for elementary school-aged children. This research utilized } \\
\text { descriptive qualitative research. The subjects of this study were four children and four parents. } \\
\text { This study was carried out in Desa Sumbersari, Kecamatan Kayen Kabupaten Pati. Data } \\
\text { collection techniques and instruments used in this study were observation, interviews and } \\
\text { documentation. The data were analyzed through qualitative data analysis with reference to the } \\
\text { concept of Miles and Huberman. The results of this study indicated that there was an impact on } \\
\text { each parent's parenting style.Different parenting patterns resulted in different parenting } \\
\text { effects. Children with authoritarian parenting showed a lack of manners in actions and } \\
\text { language. Children with permissive parenting demonstrated a lack of politeness in language, } \\
\text { but possessed a good manners of action. Lastly, children with democratic parenting showed } \\
\text { language politeness and good actions. } \\
\text { Keywords: pareting patterns, politeness }\end{array}$ \\
\hline
\end{tabular}

Accepted:

02 Agustus 2021

$02^{\text {th }}$ August 2021

Published:

27 Agustus 2021

$27^{\text {th }}$ August 2021
Abstrak: Tujuan dari penelitian ini ialah untuk mengetahui dan mendeskripsikan dampak pola asuh terhadap pemaknaan sikap sopan santun anak usia sekolah dasar. Penelitian ini menggunakan jenis penelitian kualitatif deskriptif. Subjek dalam penelitian ini yaitu empat anak dan empat orang tua. Penelitian ini telah dilaksanakan di Desa Sumbersari Kecamatan Kayen Kabupaten Pati. Teknik dan instrumen pengumpulan data yang dipakai dalam penelitian ini adalah observasi, wawancara dan dokumentasi. Analisis data yang digunakan ialah analisis data kualitatif dengan mengacu kepada konsep dari Miles dan Huberman. Hasil dari penelitian ini menunjukkan bahwa terdapat dampak dari masing-masing pola asuh orang tua. Pola asuh yang berbeda menyebabkan dampak pola asuh yang berbeda-beda juga. Anak dengan pola asuh otoriter mengakibatkan kurangnya sopan santun dalam tindakan dan berbahasa. Anak dengan pola asuh permisif mengakibatkan kurangnya sopan santun dalam berbahasa, namun memiliki sopan santun tindakan yang baik. Anak dengan pola asuh demokratis mengakibatkan sopan santun dalam berbahasa maupun tindakan yang baik

Kata Kunci: pola asuh orang tua, sopan santun

\section{CITATION}

Solehah, E. E. N., Ardianti, S. D., \& Purbasari, I. (2021). The Impact of Parenting Patterns in Signifying Politeness of Elementary School Children. Primary: Jurnal Pendidikan Guru Sekolah Dasar, $10 \quad$ (4), 924-933. http://dx.doi.org/10.33578/jpfkip.v10i4.8491 .

\section{PENDAHULUAN}

Keluarga merupakan lingkungan pertama yang dikenal oleh anak serta menjadi wadah untuk menumbuhkan eksistensi dirinya. Keluarga akan memberikan kontribusi yang dominan dalam pembentukan karakter anak. Masing-masing keluarga memiliki aturan yang berbeda dalam membentuk karakter anak. Salah satu karakter yang harus 
dimiliki anak adalah sopan santun. Pola asuh orang tua memiliki dampak terhadap sikap sopan santun anak.

Pola asuh merupakan sikap maupun tindakan orang tua dalam melakukan proses interaksi, membimbing, serta mendidik anak agar dapat mencapai perkembangan spiritual, fisik, sosial, emosi dan intelektual. Rizal (2016:32) mendeskripsikan bahwa pola asuh sebagai pola perilaku yang diterapkan pada anak dan bersifat relatif konsisten dari waktu ke waktu. Terdapat tiga jenis pola asuh menurut Omrod (2010: 95) yaitu pola asuh demokratis, pola asuh permisif, dan pola asuh otoritarian.

Perilaku sopan santun merupakan sikap yang dimiliki seseorang dalam mengikuti aturan atau tata cara yang berkembang di masyarakat secara turun temurun. Chazawi (2007) menjelaskan bahwa terdapat dua jenis sopan santun yang dilakukan oleh individu, yaitu (1) Sopan santun dalam berbahasa. (2) Sopan santun dalam berperilaku. Sikap sopan santun merupakan salah satu wujud penanaman karakter dalam pelaksanaan pola asuh orang tua. Namun dewasa ini banyak sekali anak-anak yang mengalami degradasi moral sopan santun. Anak-anak sering membantah orang tua, kurang menghormati orang yang lebih tua, tidak menggunakan bahasa yang baik dan benar, serta jarang menggunakan kata tolong ketika meminta bantuan.

Anak-anak usia sekolah dasar di desa Sumbersari memiliki sikap sosial yang baik, contohnya gotong royong, kekerabatan, saling menyayangi, dan persaudaraan. Sikap sosial yang baik tersebut terwujud karena belum adanya pengaruh dari gadget, percakapan atau tali komunitas masih dilakukan secara manual atau bertemu langsung sambil bermain atau rutinitas lainnya. Hal tersebut menjadi baik karena mereka tetap mengutamakan adanya sosialisasi, anak masih memegang teguh sikap disiplinnya dalam ibadah maupun perihal sekolah, namun terdapat juga hal buruk yang terjadi. Sikap kekerabatan dan persaudaraan yang terjadi menyebabkan anak memiliki keburukan gaya bahasa bahkan mereka menggunakan bahasa yang kasar.

Bahasa kasar yang sering dilontarkan anak dalam percakapannya berawal dari kebiasaan anak mendengar percakapan orang lain yang lebih tua. Orang yang lebih tua juga tidak menunjukkan batasan berbicara jika ada anak kecil yang berada di dekatnya atau memberikan edukasi berbahasa yang sopan dan santun kepada anak. Hal tersebut yang menyebabkan anak tidak mengerti bahwa berbicara menggunakan bahasa yang kasar atau misuh merupakan salah satu sikap sopan santun yang buruk. Kebiasaan anak yang gemar berbahasa kasar itu perlu adanya pengawasan dan bimbingan dengan cara mengetahui bagaimana dampak dari pola asuh orang tua dalam sopan santun anak yang telah diterapkan selama ini.

\section{KAJIAN TEORI \\ Pola Asuh Orang Tua}

Rizal (2016:32) mendeskripsikan pola asuh sebagai pola perilaku yang diterapkan pada anak dan bersifat relatif konsisten dari waktu ke waktu. Pola perilaku ini dapat dirasakan oleh anak, dari segi negatif maupun positif. Pola asuh merupakan proses interaksi antara orang tua dan anak dalam mendukung perkembangan fisik, sosial, emosi, intelektual dan spiritual sejak fase anak dalam kandungan hingga dewasa 
(Sukiman, 2016:2). Listya (2015:101) mendeskripsikan pola asuh orang tua sebagai sikap orang tua dalam berinteraksi, membimbing, membina, dan mendidik anak-anaknya dalam kehidupan sehari-hari dengan harapan menjadikan anak sukses menjalani kehidupan ini. Dengan pola asuh yang diterapkan orang tua anak dapat berinteraksi dengan lingkungan mengenai dunia sekitar serta mengenal pergaulan hidup yang berlaku dilingkungannya. Berdasarkan penjabaran tersebut, maka dapat disimpulkan bahwa pola asuh merupakan sikap atau tindakan orang tua dalam melakukan proses interaksi, membimbing, serta mendidik anak agar dapat mencapai perkembangan spiritual, fisik, sosial, emosi dan intelektual.

Omrod (2010: 95) berpendapat bahwa terdapat tiga jenis pola asuh, yaitu pola asuh demokratis, pola asuh permisif, dan pola asuh otoriter. Pola asuh demokratis merupakan jenis pola asuh yang membebaskan anak namun masih mengontrol kegiatan anak dengan cara mengajak diskusi guna menjalin keakraban dengan anak. Pola asuh permisif ialah jenis pola asuh yang cenderung membebaskan anak melakukan apapun yang diinginkan. Pola asuh otoriter yaitu jenis pola asuh yang sifatnya mengekang atau memaksa anak, dengan kata lain anak tidak diberi kesempatan untuk menyampaikan pendapatnya.

Menurut Tridhonanto (2014 : 1317) berikut ini merupakan dampak dari setiap pola asuh orang tua yang akan mempengaruhi sikap dan sifat anak :

a. Pola asuh otoriter

Dampak yang ditimbulkan oleh pola asuh otoriter antara lain : mudah tersinggung, penakut, pemurung dan merasa tidak bahagia, mudah terpengaruh, mudah stress, tidak mempunyai arah masa depan yang jelas, dan tidak bersahabat.

b. Pola asuh permisif

Dampak yang ditimbulkan antara lain : sikap agresif, suka memberontak, kurang percaya diri dan pengendalian diri, suka mendominasi, tidak jelas arah hidupnya, dan prestasi rendah.

c. Pola asuh demokratis

Dampaknya antara lain : memiliki rasa percaya diri, bersikap bersahabat, mampu mengendalikan diri, mau bekerja sama, rasa ingin tahu tinggi, arah dan tujuan hidup jelas, dan berorientasi pada prestasi.

\section{Sikap Sopan Santun}

Menurut Cowley (dalam Faridah, 2016:3) menjelaskan perilaku sopan santun adalah bagian dari perilaku diri yang terekspresi dari moral. Sopan santun merupakan ekspresi dari sikap rendah hati dan merupakan sesuatu yang dihasilkan dari hati nurani, yang diekspresikan dalam perilaku dan cara berpikir dalam integritas pribadi dalam konsistensi perilaku. Djahiri (dalam Sagala, dll, 2017:2), perilaku sopan santun merupakan bagian dari ekspresi moral seseorang. Sopan santun merupakan ekspresi dari sikap rendah hati serta sesuatu yang dihasilkan dari hati nurani dan diwujudkan dalam perilaku maupun cara berfikir dalam integritas pribadi. Orang-orang yang memiliki sopan santun, berarti ia memiliki etika dan tahu bagaimana cara menempatkan dirinya diberbagai kehidupan. Sopan santun sangat diperlukan dalam berinteraksi dan bergaul agar terdapat keselarasan dalam berperilaku (Cahyaningsih, Nurdia (2017:43). Berdasarkan penjabaran tersebut maka dapat disimpulkan bahwa perilaku sopan santun merupakan sikap 
yang dimiliki seseorang dalam mengikuti aturan atau tata cara yang berkembang di masyarakat secara turun temurun. Sikap sopan santun menjadikan individu memahami cara menempatkan diri dalam kehidupan bermasyarakat. Seseorang yang memiliki sikap sopan santun memiliki integritas yang tinggi sehingga dapat diterima di masyarakat dengan baik.

Chazawi (2007) menjelaskan bahwa terdapat dua jenis sopan santun yang dilakukan oleh individu, yaitu :

1) Sopan santun dalam berbahasa

Santun bahasa menunjukan bagaimana seseorang melakukan interaksi sosial dalam kehidupannya secara lisan. Setiap orang harus menjaga santun bahasa agar komunikasi dan interaksi dapat berjalan baik. Bahasa yang dipergunakan dalam sebuah komunikasi sangat menentukan keberhasilan pembicaraan.

2) Sopan santun dalam berperilaku.

Sopan santun dalam berperilaku dapat diimplementasikan dengan cara memperlakukan orang lain. Setiap orang harus memperlakukan orang lain dengan baik dan sesuai aturan atau norma yang berlaku. Segala tindak tanduk yang dilakukan harus sesuai dengan norma kesopanan yang berlaku di setiap daerah.

\section{METODE PENELITIAN}

Penelitian ini telah dilaksanakan di Desa Sumbersari Kecamatan Kayen Kabupaten Pati. Metode yang digunakan dalam penelitian yaitu metode deskriptif kualitatif. Hal ini sesuai dengan tujuan penelitian yaitu mendeskripsikan pola asuh orang tua dalam pemaknaan sikap sopan santun anak usia sekolah dasar. Penelitian kualitatif bermaksud untuk memahami fenomena tentang apa yang dialami oleh subjek penelitian misalnya perilaku, persepsi, motivasi, tindakan dan lain lain secara holistik, dan dengan cara deskripsi dalam bentuk kata kata dan bahasa, pada suatu konteks khusus yang alamiah dan dengan memanfaatkan berbagai metode alamiah (Moleong, 2017 :6). Subjek dalam penelitian ini ialah anak kelas 5 SD yang berjumlah empat orang dan orang tua yang berjumlah empat orang berdasarkan jenis pekerjaannya. Peneliti menggunakan tiga teknik dalam pengumpulan data, yaitu observasi, wawancara, dan dokumentasi. Teknik pengumpulan data yang pertama, melalui observasi yang dilakukan dalam penelitian ini adalah observasi partisipan. Kegiatan observasi ini dilakukan dengan orang tua dan anak. Observasi yang dilakukan dengan orang tua yaitu untuk mengetahui pola asuh yang diterapkan di rumah. Adapun observasi yang dilakukan dengan anak yaitu untuk mengetahui pola asuh orang tua dan dampak pola asuh yang diterapkan oleh orang tua. Wawancara yang digunakan dalam penelitian ini merupakan wawancara semi terstruktur. Wawancara semi terstruktur yaitu wawancara yang pelaksanaanya lebih bebas bila dibandingkan dengan wawancara terstruktur, sehingga responden memiliki kesempatan yang luas untuk menyampaikan pendapatnya.

Wawancara dilakukan dengan orang tua dan anak. Wawancara yang dilakukan dengan orang tua difokuskan pada cara menanamkan sikap sopan santun pada anak. Adapun wawancara yang dilakukan dengan anak difokuskan pada indikator sopan santun. Dalam penelitian ini, peneliti menggunakan dokumentasi yang berbentuk tulisan dan gambar berupa foto saat melakukan wawancara dengan anak dan orang tua. Kegiatan penelitian ini 
berlangsung mulai tanggal 10 Maret 2021 hingga 17 April 2021, mulai dari tahap observasi hingga wawancara. Wawancara yang dilakukan sebanyak tiga kali kepada setiap anak dan orang tua. Untuk memeriksa keabsahan data dalam penelitian ini, peneliti menggunakan tiga kriteria yaitu uji kredibilitas, uji dependabilitas, dan uji konfirmabilitas. Kemudian peneliti menganalisis data dengan mengacu pada konsep Miles dan Huberman. Miles dan Huberman dalam (Sugiyono, 2015: 133) mengemukakan bahwa aktivitas dalam analisis data kualitatif dilakukan secara interaktif dan berlangsung secara terus menerus sampai tuntas, sehingga datanya sudah jenuh. Aktivitas dalam analisis data, yaitu pengumpulan data (data collection), reduksi data (data reduction), penyajian data (data display), dan penarikan kesimpulan (conclusion drawing/verification) yang disajikan secara interaktif.

\section{HASIL DAN PEMBAHASAN}

Pada hasil penelitian ini, peneliti akan memaparkan beberapa hasil temuan ketika melakukan penelitian mengenai Dampak Pola Asuh Orang Tua dalam Pemaknaan Sikap Sopan Santun Anak Usia Sekolah Dasar di Desa Sumbersari Kecamatan Kayen Kabupaten Pati. Penelitian yang dimulai pada bulan Maret 2021 hingga bulan April 2021 menghasilkan beberapa temuan mengenai Dampak Pola Asuh dalam Pemaknaan Sopan Santun.

Pola asuh ialah tindakan orang tua dalam melakukan proses interaksi, membimbing, serta mendidik anak agar dapat mencapai perkembangan spiritual, fisik, sosial, emosi dan intelektual.
Menurut Ardianti, Dkk (2021) pola asuh orang tua ialah sesuatu yang dilakukan oleh orang tua guna untuk membimbing, melatih, mendidik serta memberi contoh pada anak di kehidupan sehari-hari. Pola asuh orang tua yang diterapkan kepada anak dalam kehidupan sehari-hari pasti akan memberikan suatu dampak terhadap anak tersebut. Sesuai pendapat Hasanah (2016: 82) yang menyebutkan bahwa pola asuh memberikan dampak signifikan untuk perkembangan perilaku anak melalui berbagai hal. Faizah (2021: 14) berpendapat, bentuk perhatian dan kasih sayang yang ditanamkan dan dicurahkan oleh orang tua kepada anak dengan segenap hati membuat anak memiliki sikap sopan santun yang baik dalam berinteraksi. Dengan kata lain, semakin baik pola asuh orang tua semakin baik pula perilaku sopan santun anak, begitu pula sebaliknya (Risthantri, 2015: 199). Perilaku sopan santun merupakan sikap yang dimiliki seseorang dalam mengikuti aturan atau tata cara yang berkembang di masyarakat secara turun temurun. Terdapat pula cara untuk menanamkan sikap sopan santun kepada anak, yaitu dengan memberikan contoh, memberikan keteladanan, melakukan pembiasaan, keterlibatan dengan orang tua, memberikan penguatan tentang sikap sopan santun. Pemaknaan sikap sopan santun setiap anak dengan anak lainnya tentu berbeda tergantung dengan bagaimana cara orang tua mendidik anak. Aslan (2019: 32) menyampaikan bahwa sikap anak yang berbeda-beda disebabkan karena bentuk pola asuh yang diberikan oleh orang tua berbeda-beda pula.

Menurut Omrod (2010: 95) yang berpendapat bahwa terdapat tiga jenis pola asuh, yaitu pola asuh demokratis, pola asuh 
permisif, dan pola asuh otoriter. Seperti halnya yang terjadi di Desa Sumbersari selama penelitian kepada empat keluarga yang menerapkan pola asuh yang berbeda sehingga menimbulkan dampak yang berbeda pula, seperti :

1. Pola asuh otoriter

Pola asuh otoriter ialah jenis pola asuh yang cenderung menetapkan standart yang mutlak harus dituruti. Orang tua tipe ini cenderung bersifat memaksa, memerintah, menghukum. Orang tua beranggapan bahwa anak harus mengikuti aturan yang ditetapkan, karena peraturan yang ditetapkannya semata mata demi kebaikan anak.

Hasil observasi menunjukkan bahwa ibu VS memiliki peraturan yang bersifat memaksakan kehendak pada anak (FR), menerapkan sikap kedisiplinan yang keras pada anak (FR), membatasi kegiatan anak di luar rumah serta menghukum anak apabila melakukan kesalahan. Namun Ibu VS juga telah memberi teladan yang baik pada anak perihal menajalankan ibadah. Hal ini diperkuat dengan pendapat Ibu VS saat wawancara yang menyebutkan bahwa mendidik anak dengan keras dapat membuat anak patuh terhadap aturan yang dibuat orang tua, disiplin waktu dalam belajar, serta selalu mengucapkan terima kasih setelah mendapatkan pertolongan dari orang lain.

"Saya selalu mengajak anak untuk belajar tepat waktu karena saya pengen memiliki anak yang pintar agar bisa sukses di masa depan.

Saya juga membatasi kegiatan mainnya diluar karena khawatir terpengaruh hal yang tidak baik diluar rumah".

Dengan pola asuh yang diterapkan oleh ibu VS memberikan dua dampak terhadap sikap sopan santun anak (FR). Yang pertama berdampak pada sikap sopan santun dalam tindakan. Sikap sopan santun dalam tindakan yang kurang baik, hal ini dibuktikan dengan anak tidak suka menyapa orang lain, lebih bersikap dingin kepada orang lain, dan kurang menghormati orang lain. Yang kedua berdampak pada sikap sopan santun dalam berbahasa. Sikap sopan santun dalam berbahasa yang kurang baik pula, dibuktikan dengan anak pernah memotong pembicaraan orang lain, pernah berkata kasar, membentak dan mengejek teman ketika diluar rumah. Namun terlepas dari itu semua anak juga masih memiliki kebiasaan baik yakni meminta tolong dengan mengucapkan kata "tolong" serta berterima kasih jika telah diberikan bantuan. Pola asuh yang diterabkan ibu VS membuat anak tidak bisa mengendalikan emosi ketika berinteraksi dengan orang lain atau ketika teman mengejeknya anak bisa marah dan berkata kasar. Rakhmawati (2015: 5) berpendapat bahwa pola asuh otoriter dapat memberikan dampak negatif pada perkembangan psikologis anak, anak kemudian cenderung tidak dapat mengendalikan diri dan emosi bila berinteraksi dengan orang lain.

\section{Pola asuh permisif}

Pola asuh permisif merupakan jenis pola asuh yang memberikan pengawasan sangat longgar dan memberikan kesempatan kepada anak untuk melakukan sesuatu tanpa pengawasan yang cukup dari orang tua. Mereka cenderung tidak menegur atau memperingatkan anak apabila anak sedang dalam keadaan bahaya, dan sangat sedikit bimbingan yang diberikan oleh mereka. 
Hasil observasi menunjukkan bahwa ibu UL memberikan kebebasan pada anak dalam melakukan hal apapun, selalu mendukung kegiatan anak, dan juga tidak pernah memarahi atau menghukum anak. Hal tersebut diperkuat saat wawancara dengan ibu UL yang mengungkapkan bahwa beliau tidak banyak menuntut anak, anak diberikan kebebasan melakukan yang disukainya selama masih dalam kegiatan positif.

"Saya selalu mendukung apa yang terbaik buat anak, selagi itu kegiatan positif".

Berdasarkan pola asuh yang diterapkan oleh ibu UL memberikan dua dampak terhadap sikap sopan santun anak (SNNA). Yang pertama yaitu berdampak pada sikap sopan santun dalam tindakan. Anak memiliki sikap sopan santun dalam tindakan yang baik, dibuktikan dengan anak menghormati orang lain, telah menerapkan salam senyum sapa, dan tidak mengejek teman. Yang kedua yaitu berdampak pada sikap sopan santun dalam berbahasa. Anak memiliki sikap sopan santun dalam berbahasa yang kurang baik, hal ini dibuktikan dengan pernah berkata kasar ketika diejek teman, namun tidak suka jika ada yang berkata kasar padanya. Anak kurang menghargai pendapat orang lain, hal ini ditunjukkan dengan sering memotong pembicaraan dan membantah pendapat orang lain. Anak juga sering meludah disembarang tempat, namun tidak tau jikalau perilaku tersebut tidak baik. Namun anak masih memiliki sopan santun yang baik, mengucapkan terima kasih setelah mendapatkan bantuan dari orang lain. Pola asuh yang diterapkan oleh ibu UL cenderung mengakibatkan anak menjadi egosi dan manja. Sejalan dengan Rakhmawati (2015:6) yang menyatakan bahwa pola asuh permisif dapat mengakibatkan anak menjadi egois karena orang tua cenderung memanjakan anak dengan materi.

\section{Pola asuh demokratis}

Pola asuh demokratis merupakan jenis pola asuh yang memberikan kebebasan pada anak namun masih mengontrol dan mengawasi yang dilakukan anak. Pola asuh ini selalu mengajak anak untuk berdiskusi terlebih dahulu sebelum mengambil keputusan. Menurut Purbasari, dkk (2020), pola asuh demokratis merupakan pola asuh orang tua yang dapat bekerja sama juga bersifat kooperatif, dalam mendampingi anak di kehidupan sehari-hari. Pola asuh demokratis cenderung tidak menuntut banyak kepada anak. Pada penelitian ini terdapat dua keluarga yang menerapkan pola asuh demokratis, yaitu oleh keluarga ibu APS dan ibu K.

Pada keluarga ibu APS, hasil observasi menunjukkan bahwa ibu APS selalu mengajak anak untuk berdiskusi ketika malam hari setelah mendampingi anak (CDW) belajar, keluarga ibu APS selalu memberikan nasehat kepada anak perihal kesopanan dan orang tua juga memberikan kesempatan kepada anak untuk menyelesaikan masalahnhya sendiri. Hal tersebut diperkuat dengan hasil wawancara dengan ibu APS bahwa beliau selalu menyempatkan diri untuk berdiskusi dengan anak, mengawasi kegiatan anak, serta mengambil keputusan dengan cara mendiskusikan terlebih dahulu kepada anak.

"Saya selalu mengingatkan anak anak untuk rajin belajar. Saya juga memantau hasil belajar anak, biasanya pada saat ngobrol 
setelah makan malam saya gunakan untuk memberikan nasehat atau motivasi kepada anak baik tentang hasil belajar maupun penanaman nilai nilai sopan santun".

Berdasarkan pola asuh yang diterapkan oleh ibu APS memberikan dua dampak terhadap sikap sopan santun anak (CDW). Yang pertama yaitu memberikan dampak pada sikap sopan santun dalam tindakan yang baik, hal tersebut dibuktikan dengan anak bersikap patuh pada orang tua dan anak juga menerapkan budaya $3 \mathrm{~S}$ (salam, senyum, sapa) ketika di rumah maupun di sekolah. Yang kedua yaitu memberikan dampak pada sikap sopan santun dalam berbahasa yang baik pula, dibuktikan dengan anak tidak pernah berkata kasar, selalu menghargai pendapat orang lain atau tidak pernah memotong dan membantah pendapat orang lain.

Pada keluarga ibu K, menurut hasil observasi, ibu $\mathrm{K}$ memberikan kebebasan yang bertanggung jawab kepada anak (MAIS). Orang tua memberikan kesempatan kepada anak untuk menyampaikan pendapatnya. Hal ini dikuatkan dengan wawancara ibu $\mathrm{K}$ selalu mengajak diskusi anak apabila memutuskan sesuatu, orang tua juga memberikan anak kesempatan untuk menyampaikan keinginan dan pendapatnya.

"Saya selalu mengajak diskusi dan mencoba mendengarkan apa yang menjadi keinginan anak".

Namun terdapat kendala yang sering kali dihadapi oleh ibu K yakni anak mudah terpengaruh dengan anak yang lain. Berdasarkan pola asuh yang diterapkan oleh ibu $\mathrm{K}$ memberikan dua dampak terhadap sikap sopan santun anak (MAIS).
Yang pertama yaitu berdampak pada sikap sopan santun dalam tindakan. Sopan santun dalam tindakan yang baik, dibuktikan dengan anak memiliki sikap hormat yang baik kepada orang tua, anak selalu meminta ijin ketika meminjam barang, dan memasuki ruangan dengan mengucap salam. Yang kedua yaitu bedampak pada sikap sopan santun dalam berbahasa. Sopan santun dalam berbahasa yang kurang baik, hal ini dibuktikan dengan pernah berkata kasar kalau ada yang mengejeknya, namun ketika diejek oleh temannya, (MAIS) berusaha agar tidak membalasnya, terkadang juga memotong pembicaraan orang lain, namun itu jarang sekali. Anak selalu menggunakan kata tolong dan meminta maaf jika melakukan kesalahan.

Pola asuh yang diterapkan oleh ibu APS dan ibu $\mathrm{K}$ mengakibatkan anak menjadi lebih percaya diri dan berani mengungkapkan pendapat mereka. Senada dengan pendapat Faizah (2021) dimana penanaman sikap sopan santun dengan pola asuh demokratis membuat anak lebih aktif saat berinteraksi dengan orang lain, menghormati orang lain, berani mengungkapkan pendapat, dan mendengarkan teman atau orang lain saat sedang berbicara.

\section{SIMPULAN DAN REKOMENDASI}

Berdasarkan hasil pembahasan yang telah dijelaskan oleh peneliti mengenai Dampak Pola Asuh Orang Tua dalam Pemaknaan Sikap Sopan Santun Anak Usia Sekolah Dasar, masing-masing pola asuh yang diterapkan tentunya memberikan dampak yang berbeda. Berikut kesimpulan yang dapat peneliti ambil dari penelitian yang telah dilaksanakan. Dampak dari pola asuh 
otoriter yang diterapkan di keluarga dalam sopan santun mengakitbatkan anak (FR) kurang memiliki sopan santun dalam tindakan dan kurang sopan dalam berbahasa. Dampak dari pola asuh permisif yang diterapkan dikeluarga dalam sopan santun mengakibatkan anak (SNNA) memiliki sopan santun dalam tindakan yang baik, namun memiliki sikap sopan santun dalam berbahasa yang kurang baik. Dampak dari pola asuh demokratis yang diterapkan dikeluarga yaitu mengakibatkan anak (CDW) memiliki sopan santun dalam tindakan dan sopan santun dalam berbahasa yang baik. Lalu pada anak (MAIS) memiliki sopan santun dalam tindakan yang baik namun kurang memiliki sopan santun dalam berbahasa yang kurang baik.

Berdasarkan penelitian yang telah dilakukan di Desa Sumbersari Kecamatan Kayen Kabupaten Pati, peneliti dapat memberikan saran sebagai berikut : 1) Bagi orang tua, orang tua dapat menerapkan pola asuh yang tepat dan sesuai perkembangan anak sehingga dapat menanamkan sikap sopan santun dengan optimal, 2) Bagi anak, anak dapat memilih teman dari lingkungan yang tepat dan baik untuk dirinya, dan anak dapat meneladani dan menjalankan nasehat yang diberikan orang tua berkaitan dengan nilai sopan santun, 3) Bagi masyarakat, masyarakat dapat ikut serta membangun lingkungan yang kondusif dan memberikan contoh serta keteladanan bagi anak anak, 4) Bagi peneliti selanjutnya, peneliti selanjutnya harus lebih memperhatikan dan melakukan pendekatan secara intensif kepada orang tua dan anak sehingga informasi yang dikumpulkan dapat tergali lebih banyak.

\section{DAFTAR PUSTAKA}

Ardianti, S. D., Khamdun., \& Rositania, L.W. (2021). Pola Asuh Orang Tua Dalam Pembentukan Disiplin Belajar Anak Selama Pembelajaran Daring Di Desa Trangkil Rw 02. Jurnal Edukasi Tematik. 2 (1), 30-42.

Aslam. (2019). Peran Pola Asuh Orang Tua di Era Digital. Jurnal Studia Isnania, 7(1), 20-34

Cahyaningsih, N. (2017). Skripsi. Pendidikan Akhlak : Pembinaan Sikap Sopan Siswa Terhadap Guru Di Mts Negeri I Rakit Kecamatan Rakit Kabupaten Banjarnegara.

Chazawi, A. (2017). Tindak Pidana Kesopanan. Jakarta: Rajawali Pos.

Faizah, R. N., Fajrie, N., \& Rahayu, R. (2021). Sikap Sopan Santun Anak Dilihat Dari Pola Asuh Orang Tua Tunggal. Jurnal Prasasti Ilmu. 1(1), 13-18.

Faridah, F., \& Halida. (2016). Peningkatan Perilaku Sopan Santun Pada Anak Usia 5-6 Tahun Di Taman Kanak-Kanak PGRI Ketapang. Jurnal Universitas Tanjung Pura 1 (1), 1-12.

Fitriyani, L. (2015). Peran Pola Asuh Orang Tua Dalam

Mengembangkan Kecerdasan Emosi Anak. Jurnal Lentera. 18 (1), 93-110.

Hasanah, U. (2016). Pola Asuh Orang Tua Dalam embentuk Karakter Anak. Jurnal Elementary, 2(2), 72-82.

Moleong, L. J. (2017). Metode Penelitian Kualitatif, cetakan ke-36, 
Bandung: PT. Remaja Rosdakarya Offset.

Ormrod, J. E. (2010). Psikologi Pendidikan Membantu Siswa Tumbuh dan Berkembang. Erlangga, 2010. ed. 9.

Purbasari, I., Handayani, R., \& Setiawan, D. (2020). Tipe Pola Asuh Dalam Pendidikan Keluarga. Jurnal Refleksi Edukatika., 11 (1), 16-23.

Rakhmawati, I. (2015). Peran Keluarga Dalam Pengasuhan Anak. Jurnal Bimbingan Konseling Islam: KONSELING RELIGI, 1(6), 118.

Rizal, M., \& Fatchur. (2016). Skripsi. Pola Asuh Keluarga Dalam Membimbing Perilaku Sosial Anak (Studi Kaslilisus Pada Keluarga Tenaga Kerja Indonesia di Desa Tamangede Kecamatan Gemuh Kabupaten Kendal).

Risthantri, P., \& Sudrajat, A. (2015). Hubungan Antara Pola Asuh Orang Tua dan Ketaatan Beribadah Dengan Perilaku Sopan Santun Peserta Didik. Harmoni Sosial: Jurnal Pendidikan IPS, 2 (2), 191-202.

Sagala., \& Dian, M. (2017). Peningkatan Perilaku Sopan Santun Melalui Metode Bercerita Pada Anak Usia 5-6 Tahun Di TK LKIA II Pontianak Selatan. Jurnal Universitas Tanjung Pura 1 (1), 1-7.

Sugiyono. (2015). Metode Penelitian Kuantitatif. Kualitatif dan $R \& D$. Bandung: Alfabeta.
Sukiman. (2010). Seri Pengasuhan Positif. Jakarta : Kemendikbud.

Tridhonanto, A., \& Beranda, A. (2014). Mengembangkan Pola Asuh Demokratis. Jakarta: PT Elex Media Kompurindo. 